\title{
Town in the Empire Government, Politics, and Society in Seventeenth-Century Popayán
}

\section{Peter Marzahl}

Institute of Latin American Studies

The University of Texas at Austin 
International Standard Book Number 0-292-78028-1 (cloth)

0-292-78029-X (paper)

Library of Congress Catalog Card Number 77-620062

Copyright (C) 1978 by Peter Marzahl

All rights reserved

Printed in the United States of America

The Latin American Monographs Series is distributed for the Institute of Latin American Studies by:

University of Texas Press

P. O. Box 7819

Austin, Texas 78712 


\section{For Dietrich Gerhard}


THIS PAGE INTENTIONALLY LEFT BLANK 